\title{
Habitat architecture influencing microcrustaceans composition: a case study on freshwater Cladocera (Crustacea Branchiopoda)
}

\author{
J. R. Debastiani-Júnior ${ }^{*}$, L. M. A. Elmoor-Loureiro ${ }^{b}$ and M. G. Nogueira ${ }^{a}$

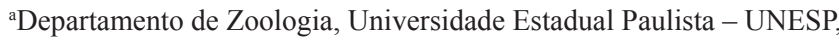 \\ Distrito de Rubião Júnior, s/n, CEP 18618-970, Botucatu, SP, Brazil \\ bLaboratorio de Biodiversidade Aquática, Universidade Católica de Brasília - UCB, \\ QS 7 lote 1, sala M204, CEP 71966-700, Taguatinga, DF, Brazil \\ *e-mail: debastianijunior@gmail.com
}

Received: July 21, 2014 - Accepted: October 24, 2014 - Distributed: February 29, 2016

(With 4 figures)

\begin{abstract}
Environmental complexity is considered a key factor for diversity enhancement in aquatic ecosystems. Macrophyte stands are a major contributor for this complexity due to their differential architectures. Nevertheless, the influence of distinct aquatic habitat architectures (with different types of macrophytes or without them) on microcrustaceans' taxa composition, usually found in macrophyte colonized water bodies, is underexplored in limnological studies. The main objective of this study was to analyze this influence by comparing the Cladocera composition among four habitat architectures: (1) fluctuant macrophytes, (2) rooted emergent macrophytes, (3) submerged macrophytes and (4) the limnetic zone of oxbow lakes associated to a large subtropical reservoir. Wide compositional variation was observed. Fluctuant macrophytes exhibited the richest Cladocera assemblage, dominated by Chydoridae. Submerged and rooted emergent macrophytes had the most similar assemblages between them. The most distinctive fauna was found in the limnetic zone, dominated by Bosminidae. Probable differences in resource availability in each sampled habitat architecture are considered as the driving factor for the Cladocera composition variation. We concluded that for a complete inventory of a given local fauna, it is imperative to take into account the aquatic habitat architecture, including macrophyte stands, in the data sampling design.
\end{abstract}

Keywords: Cladocera, composition, macrophytes, subtropical reservoir.

\section{Arquitetura do habitat influenciando a composição taxonômica de microcrustáceos: um estudo de caso sobre Cladocera de águas continentais (Crustacea Branchiopoda)}

\section{Resumo}

A complexidade ambiental é considerada um fator chave para o aumento na diversidade de ambientes aquáticos. A presença de bancos de macrófitas é um dos principais contribuintes para tal complexidade devido às suas arquiteturas diferenciadas. Entretanto, a influência de diferentes arquiteturas de habitat (com diferentes macrófitas ou sem elas) sobre a composição taxonômica de microcrustáceos, comumente encontrados em ambientes colonizados por macrófitas, é pouco explorada em estudos limnológicos. O objetivo desse estudo foi avaliar esta influência através da comparação da composição das associações de Cladocera entre quatro arquiteturas de habitat: (1) macrófitas flutuantes, (2) macrófitas enraizadas emersas, (3) macrófitas submersas e (4) a zona limnética em lagoas laterais associadas a um grande reservatório subtropical. Ampla variação composicional foi observada. Macrófitas flutuantes apresentaram as mais ricas assembléias de Cladocera, dominadas por Chydoridae. Macrófitas submersas e emersas enraizadas apresentaram as associações mais similares. A fauna mais distinta foi a da zona limnética, dominada por Bosminidae. Prováveis diferenças na disponibilidade de recursos entre as arquiteturas de habitat amostradas foram consideradas o fator mais relevante levando à variação composicional dos microcrustáceos. Concluímos que para um inventário completo de uma determinada fauna local é imperativo que seja considerada a arquitetura dos habitats aquáticos, incluindo os bancos de macrófitas, no desenho amostral.

Palavras-chave: Cladocera, composição, macrófitas, reservatório subtropical. 


\section{Introduction}

Macrophytes can support a high associated biodiversity in the Neotropics, as observed in many regional case studies (e.g.: Meschiatti et al., 2000; Elmoor-Loureiro, 2007; Maia-Barbosa et al., 2008; Güntzel et al., 2010; Panarelli et al., 2008, 2010; Ferrareze and Nogueira, 2011). The spatial complexity generated by the aquatic plants, and the consequent increase in microhabitat availability, is a major contributing factor for its biodiversity (Nogueira et al., 2003; McAbendroth et al., 2005; Thomaz et al., 2008; Thomaz and Cunha, 2010; Ferreiro et al., 2011), especially when compared to the relatively homogeneous limnetic zones (e.g.: Maia-Barbosa et al., 2008, found increased richness in littoral vegetated habitats compared to the limnetic zone). Nevertheless, this theoretical complexity is variable according to the habitat architecture provided by the different macrophyte species or their absence.

Ferreiro et al. (2011) proposed that smaller organisms would be benefitted by higher microhabitat complexity due to a relative wider area for occupation, inaccessible for larger taxa and Grenouillet and Pont (2001) discussed that both architecture and size of plants determine the fauna species composition in macrophyte stands.

Based on the previous considerations it is expected that each physiognomic group of macrophytes and the limnetic zone exhibit a unique or at least diverse fauna composition due to differential habitat architecture.

Most investigations regarding fauna-macrophyte associations (related to habitat architecture and complexity) focus on macroinvertebrate (e.g.: Fulan and Henry, 2006; Tarkowska-Kukuryk and Kornijów, 2008; Thomaz et al., 2008) or fish assemblages (e.g.: Grenouillet and Pont, 2001). Studies that evaluate microscopic fauna composition are scarce and usually do not consider species identity (e.g.: Balcombe et al., 2007). In order to investigate the species level association between fauna and habitat architecture provided by macrophytes or their absence, Cladocera was chosen as a zoological group model. These microcrustaceans have plastic life habit, with many planktonic species as well as benthic and phytophilous ones. The last type can be found associated with macrophytes in the littoral zones, but also in fluctuating stands in the limnetic zone of lentic and lotic habitats (e.g.: Gazulha et al., 2011). The size variation of these organisms is from $\sim 400$ $\mu \mathrm{m}$ to a maximum of $\sim 2000 \mu \mathrm{m}$ in the studied region (the Jurumirim Reservoir upstream lake system) (Nogueira, 2001; Panarelli et al., 2003). Tremel et al. (2000) have already observed Cladocera composition variation between different habitat architectures in a Canadian lake, but only one macrophyte physiognomy was considered. Duigan and Kovach (1994) showed that the macrophyte diversity index was significantly correlated with the Cladocera fauna composition in Scotland, but samples were integrated among macrophytes to represent the lakes, not particular plant architectures.

Therefore, this zoological group can be a good proxy for this investigation, being this study the first to research multiple habitat architectures, considering the presence of different macrophytes and their absence, influencing on Cladocera species composition.

\section{Material and Methods}

Samplings were carried out in the end of spring 2013 (November) in lateral oxbow lakes of the upstream stretch of Jurumirim Reservoir (Figure 1), a large hydropower reservoir in the Paranapanema River (São Paulo State, Brazil), where it is observed the presence of all physiognomic macrophyte groups (Costa and Henry, 2010). For practical purposes we named the different habitat architecture by the physiognomic group of the present macrophyte or limnetic zone when plants were absent. Four habitat architectures: (1) floating macrophytes, (2) rooted emergent macrophytes, (3) submerged macrophytes and (4) the limnetic zone were sampled with a specific method, as follows (Figure 2).

- Floating macrophyte (Salvinia auriculata Aublet):

- This macrophyte has a complex spatial arrangement, mostly formed by the intricate set of filamentous roots where sediments are accumulated. To sample the habitat architecture provided by these plants a plankton net $(68 \mu \mathrm{m})$ was positioned bellow the stand and raised to isolate a circular area. The macrophytes were then washed inside this area, discarded, and the remaining water filtered through the net (Figure 2a).

- Rooted emergent macrophyte (Echinochloa polystachya (H.B.K.) Hitch):

- The spatial structure of these macrophytes is simple, a main stem from which long leafs grow. The sampling of this habitat architecture was performed by isolating a section of the stem with an acrylic tube, which was closed in both ends after cutting off the stem. The plant was washed inside the tube, discarded, and the water entrapped filtered through plankton net $(68 \mu \mathrm{m})$ (Figure 2b).

- Submerged macrophyte (Myriophyllum aquaticum (Vellozo) Verdcourt):

- These macrophytes have a considerably complex leaf system, with several empty spaces between them. The sampling of this habitat architecture was performed with an underwater hand net $(68 \mu \mathrm{m})$ through multidirectional sweeping (Figure 2c).

- Limnetic zone:

- The limnetic zone can be considered the most spatially homogeneous habitat among the ones sampled. For this architecture $5 \mathrm{~m}$ horizontal hauls with a $68 \mu \mathrm{m}$ plankton net just beneath the surface were performed (Figure 2d). 


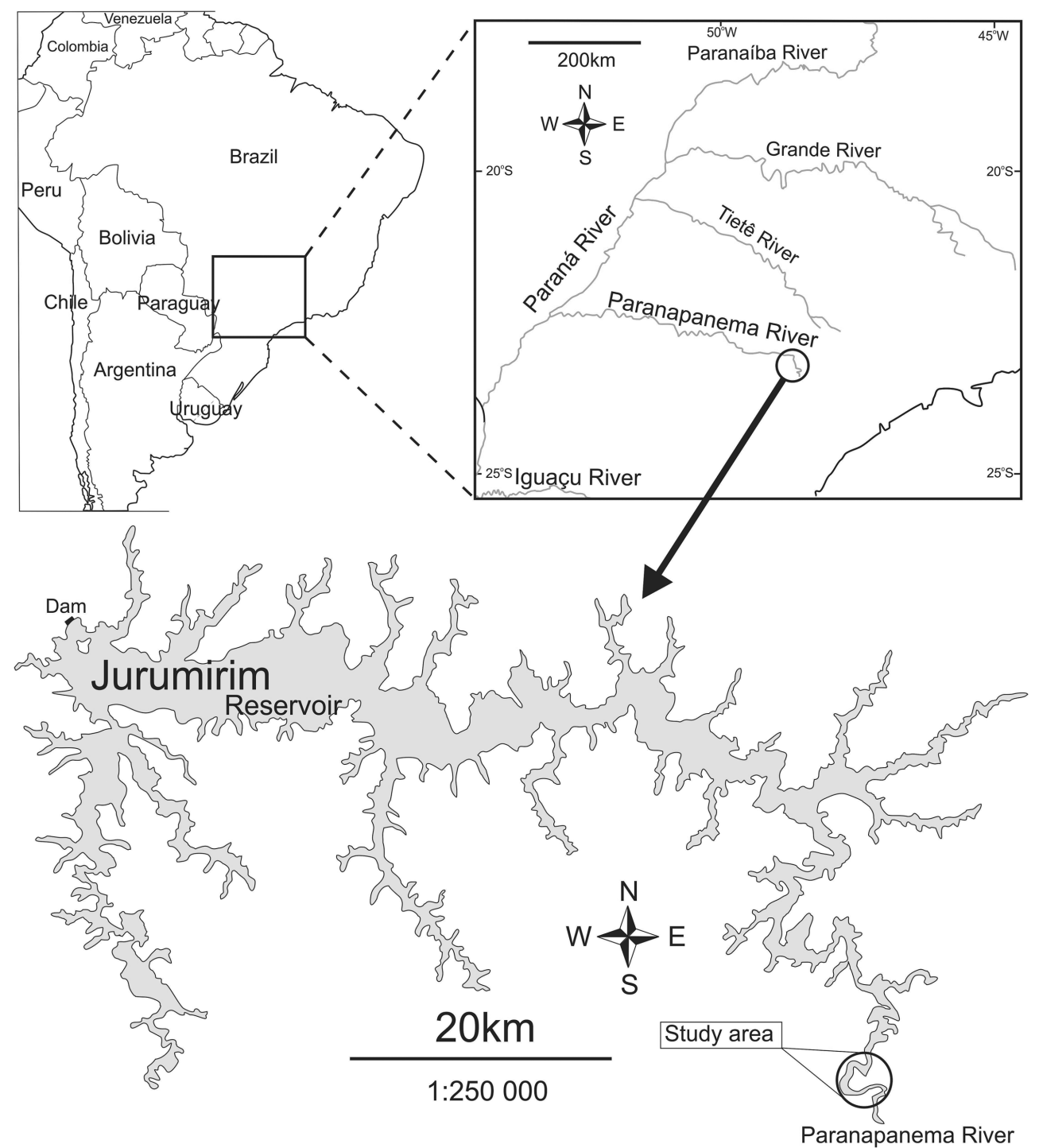

Figure 1. Geographical location and map of Jurumirim Reservoir with indication of the studied region.

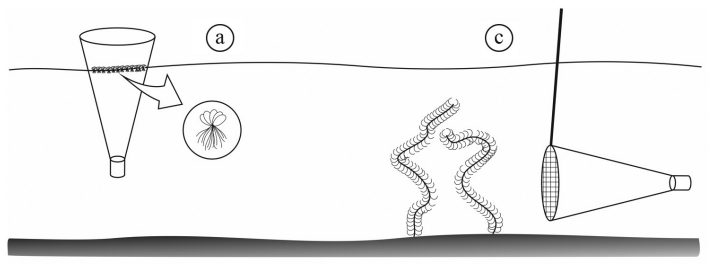

(b)

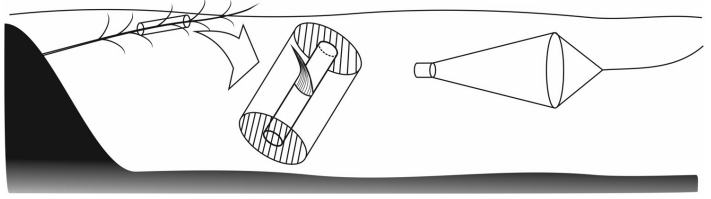

Figure 2. Illustration of the methods applied for sampling the different habitat architectures. (a) fluctuant macrophytes; (b) rooted emerged macrophytes; (c) submerged macrophytes; (d): limnetic zone.
Macrophyte stands were mono-specific and considerably isolated (some meters at least) from other macrophyte species to prevent contamination. The limnetic zone chosen was free of macrophytes on more than a $5 \mathrm{~m}$ radius and in the surface to at least visible depth.

For each habitat architecture three samples were collected, all fixed in 4\% formalin. Samples were analyzed under optical microscopy (Zeiss V6 stereomicroscope and Zeiss Standard 25 microscope). Individuals were identified to the species level trough specialized literature (Korovchinsky, 1992; Smirnov, 1992, 1996; Elmoor-Loureiro, 1997; Dumont et al., 2002; Orlova-Bienkowskaja, 1998; Kořínek, 2002; Kotov and Stifter, 2006; Sinev and Elmoor-Loureiro, 2010; Van Damme and Dumont, 2008; Van Damme et al., 2010, 2011; Elmoor-Loureiro et al., 2013). No counting was performed once the different methods have no similar area/volume metrics. In this sense, only compositional data could be considered to compare the influence of habitat 
architecture. Data was arranged for compositional similarity analysis trough Jaccard index. A species list was produced with indication of the habitat in which the species was found. Richness obtained for the different architectures was compared trough ANOVA and posterior Tukey test.

\section{Results}

A total of 29 species were identified in this study. A list of the species in each habitat architecture is presented (Table 1).
Most species (21) were found in the fluctuant macrophytes, with assemblage dominated by small benthic detritivorous and phytophilous species of the Chydoridae family, most of them (11 species) found exclusively in this habitat.

Rooted emergent and submerged macrophyte habitat architectures had the most similar species assemblage (Figure 3), with species as Latonopsis australis and Simocephalus serrulatus that can reach large body size. Alona cf. glabra was the only species exclusive to the rooted emergent habitat architecture (Table 1). No exclusive

Table 1. Species list from habitat architectures analyzed in the upstream zone of the Jurumirim Reservoir. + means presence and - absence.

\begin{tabular}{|c|c|c|c|c|}
\hline & Limnetic & Emergent & Submerged & Fluctuant \\
\hline \multicolumn{5}{|l|}{ Chydoridae Stebbing, 1902} \\
\hline \multicolumn{5}{|l|}{ Aloninae Frey, 1967} \\
\hline $\begin{array}{l}\text { Acroperus tupinamba Sinev and } \\
\text { Elmoor-Loureiro, } 2010\end{array}$ & + & - & - & - \\
\hline Alona cf. glabra Sars, 1901 & - & + & - & - \\
\hline Alona dentifera (Sars, 1901) & - & - & - & + \\
\hline Alona ossiani Sinev, 1998 & - & - & - & + \\
\hline Camptocercus australis Sars, 1896 & - & + & + & + \\
\hline Karualona muelleri (Richard, 1897) & - & - & - & + \\
\hline Leydigiopsis ornata Daday, 1905 & - & - & - & + \\
\hline Notoalona sculpta (Sars, 1901) & - & - & - & + \\
\hline Oxyurella ciliata Bergamin, 1939 & - & - & - & + \\
\hline \multicolumn{5}{|l|}{ Chydorinae Stebbing, 1902} \\
\hline Chydorus eurynotus Sars, 1901 & - & - & - & + \\
\hline Chydorus nitidulus (Sars, 1901) & - & - & - & + \\
\hline Chydorus pubescens Sars, 1901 & - & - & - & + \\
\hline Ephemeroporus hybridus (Daday, 1905) & - & - & - & + \\
\hline Pseudochydorus cf. globosus (Baird, 1850) & - & - & - & + \\
\hline \multicolumn{5}{|l|}{ Bosminidae Sars, 1985} \\
\hline Bosmina freyi Melo and Hebert, 1994 & + & - & - & - \\
\hline Bosmina hagmanni Stingelin, 1904 & + & - & - & - \\
\hline Bosmina tubicen Brehm, 1953 & + & - & - & - \\
\hline Bosminopsis deitersi Richard, 1895 & + & - & + & + \\
\hline \multicolumn{5}{|l|}{ Daphniidae Straus, 1820} \\
\hline Ceriodaphnia cornuta Sars, 1885 & + & + & + & + \\
\hline Ceriodaphnia silvestrii Daday, 1902 & + & - & - & + \\
\hline Simocephalus serrulatus (Koch, 1841) & + & + & + & + \\
\hline \multicolumn{5}{|l|}{ Ilyocryptidae Smirnov, 1992} \\
\hline Ilyocryptus spinifer Herrick, 1882 & - & + & - & + \\
\hline \multicolumn{5}{|l|}{ Macrothricidae Norman and Brandy, 1867} \\
\hline Macrothrix elegans Sars, 1901 & + & + & + & - \\
\hline Macrothrix squamosa Sars, 1901 & - & + & - & - \\
\hline \multicolumn{5}{|l|}{ Moinidae Goulden, 1968} \\
\hline Moina minuta Hansen, 1899 & + & - & - & + \\
\hline \multicolumn{5}{|l|}{ Sididae Baird, 1850} \\
\hline Diaphanosoma brevireme Sars, 1901 & - & - & + & + \\
\hline Diaphanosoma fluviatile Hansen, 1899 & + & - & - & - \\
\hline Latonopsis australis Sars, 1888 & - & + & + & + \\
\hline Sarsilatona serricauda (Sars, 1901) & - & - & - & + \\
\hline
\end{tabular}




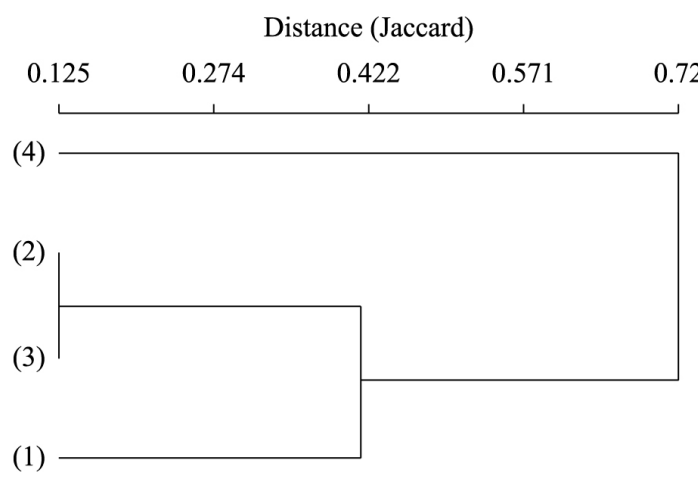

Figure 3. Cluster of the sampled habitat architectures according to the Jaccard similarity index. Codes: (1) = fluctuant macrophytes; (2) = rooted emergent macrophytes; (3) = submerged macrophytes and (4) = limnetic zone.

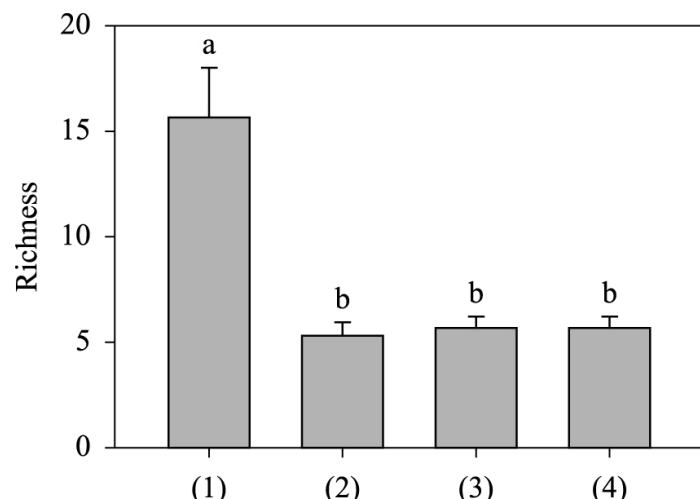

Figure 4. Mean and standard deviation of the richness found in the habitat architectures sampled in the upstream zone of the Jurumirim Reservoir. Letters represent the differences found after Tukey test ( $\mathrm{p}<0.05)$. Codes: $(1)=$ fluctuant macrophytes; (2) $=$ rooted emergent macrophytes; (3) = submerged macrophytes and (4) = limnetic zone.

species was found for the submerged macrophyte habitat architecture.

The limnetic zone habitat architecture was characterized by higher richness of true planktonic Bosminidae (3 exclusive species of this family, Table 1) and was the most divergent from all sampled habitat architectures in composition (Figure 3). Six from the 11 species found in this habitat architecture were exclusive (Table 1).

Richness calculated to the sampled habitat architectures are represented in Figure 4. Only fluctuant macrophyte habitat architecture associated richness was statistically higher from other habitat architectures. The limnetic zone did not showed lower richness as expected when compared to the rooted emergent and submerged macrophyte habitat architectures.

\section{Discussion}

Spatial complexity in water bodies is considered a driving factor for diversity enhancement (McAbendroth et al., 2005; Thomaz et al., 2008). For some species, the complexity represents a spatially larger habitat to be colonized due to micro-habitat availability (Ferreiro et al., 2011). Additionally, complex sites (e.g.: macrophyte stands) are also involved with refuge, feeding and nursery (Grenouillet and Pont, 2001; Meerhoff et al., 2007). Nevertheless, there are cases when complex sites are detrimental or a sign of danger to some species (Meerhoff et al., 2006).

Although generally enhancing complexity and, in consequence, richness and diversity, macrophytes have variable influence given their density of occupation and architecture (Tarkowska-Kukuryk and Kornijów, 2008; Hinojosa-Garro et al., 2010). In the present study the different habitat architectures provided by the macrophytes and their absence (limnetic zone) had distinct fauna composition, but only the fluctuant macrophyte habitat architecture showed significant higher species richness.

The fluctuant macrophytes habitat architecture was considered more spatially complex than the other ones due to the intricate root structure of these macrophytes. In the samples from this habitat architecture a high amount of organic matter (periphyton and detritus) was observed, being this conspicuous of this type of root system. As most of Chydoridae are substrate dwellers, feeding in periphyton and detritus (Fryer, 1968), the higher richness found in floating macrophytes and almost total exclusion from the other architectures are probably linked to this high amount of organic matter. Species capable of reaching large body size were also recorded in this habitat architecture, but no measures were made to investigate size class variation of the same species between architectures. This size class variation should be addressed in future studies to provide a further understanding of the architecture influence on cladoceran composition.

Hinojosa-Garro et al. (2010) demonstrated the influence of land use and trophic status in the development of periphyton on substrata with different structural complexity, showing that the degree of eutrophication is important for algae development in simpler habitat structures. The reservoir investigated in the present study is oligotrophic (Nogueira et al., 1999), but the area sampled in this study is considered as being more eutrophic than the rest of the reservoir and in need of a management plan for maintenance of water quality (Henry and Nogueira, 2007) and, consequently, the relationships observed between habitat architectures.

The rooted emergent and submerged macrophyte habitat architectures were similar in fauna composition and richness. Although they could be considered as different in spatial complexity (due to the differences in plant structure, but complexity was not measured) these differences were probably not enough to lead to a stronger fauna response. The available space for the organisms in these two habitat architecture, as proposed by Ferreiro et al. (2011), is probably from the same magnitude, thus leading to similar fauna. In the other hand, the absence of Chydoridae is linked to the probable lack of food resources, as discussed above. Although speculative, ontogenetic size variation can be 
related to the habitat occupation and, thus, the species common to the macrophyte habitat architectures could present differences in age classes between macrophytes. As discussed above this subject should be addressed in future researches.

The limnetic zone had a most divergent cladoceran assemblage, with high richness of planktonic Bosminidae. The genus Bosmina was found only in the limnetic habitat. The species of this family are common widespread planktonic filter feeders (e.g. Melo and Hebert, 1994; Elmoor-Loureiro, 2013) and registers for the studied reservoir has already been provided (Panarelli et al., 2008, 2010; Sartori et al., 2009). This habitat architecture is the optimal habitat for planktonic taxa, thus the increased and exclusive number of planktonic species. Nevertheless, the richness of this habitat architecture was similar to the ones from submerged and rooted emergent macrophytes, although compositionally divergent. This indicates that the considered low complexity of this architecture (due to less spatial heterogeneity) is not numerically reflected by the Cladocera fauna richness in this system. This finding support the need for habitat architecture consideration in the design of studies on Cladocera, once similar richness results could be found for compositionally divergent fauna.

The expected variation of Cladocera composition was confirmed, but only the habitat architecture provided by fluctuant macrophytes was statistically different regarding richness. The assumption that the limnetic zone would have lower richness was not corroborated. The main differences observed were linked to the probable resources (food availability or optimal habitat for true planktonic taxa) associated to the habitat architectures. Numerical similarities in the richness of compositionally divergent habitats were observed, providing the evidence that for realistic assessment of local fauna diversity all habitat architectures must be properly sampled to avoid misleading interpretations. Given this scenario, future studies must take into account the habitat architecture for data sampling design.

\section{Acknowledgements}

The authors would like to acknowledge the "Fundação de Amparo à Pesquisa do Estado de São Paulo" (FAPESP) for financial support (FAPESP processes 2009/00014-6, 2009/11781-8 and 2011/23444-6). The authors would like to also acknowledge two anonymous referees whose suggestions greatly improved this manuscript.

\section{References}

BALCOMBE, S.R., CLOSS, G.P. and SUTER, P.J., 2007. Density and distribution of epiphytic invertebrates on emergent macrophytes in a floodplain billabong. River Research and Applications, vol. 23, no. 8, pp. 843-857. http://dx.doi.org/10.1002/rra.1017.

COSTA, M.L. and HENRY, R., 2010. Phosphorus, nitrogen, and carbon contents of macrophytes in lakes lateral to a tropical river (Paranapanema River, São Paulo, Brazil). Acta Limnologica
Brasiliensia, vol. 22, no. 2, pp. 122-132. http://dx.doi.org/10.1590/ S2179-975X2010000200002

DUIGAN, C.A. and KOVACH, W.L., 1994. Relationships between littoral microcrustacea and aquatic macrophyte communities on the Isle of Skye (Scotland), with implications for the conservation of standing waters. Aquatic Conservation: Marine and Freshwater Ecosystems, vol. 4, no. 4, pp. 307-331. http://dx.doi.org/10.1002/ aqc.3270040404.

DUMONT, H.J., BRIANO, M.S. and SUBHASH BABU, K.K., 2002. A re-evaluation of the Macrothrix rosea-triserialis group, with the description of two new species (Crustacea Anomopoda: Macrothricidae). Hydrobiologia, vol. 467, no. 1-3, pp. 1-44. http:// dx.doi.org/10.1023/A:1014933227259.

ELMOOR-LOUREIRO, L.M.A., 1997. Manual de identificação de cladóceros límnicos do Brasil. Brasília: Universa. 156 p.

ELMOOR-LOUREIRO, L.M.A., 2007. Phytophilous cladocerans (Crustacea, Anomopoda and Ctenopoda) from Paranã River Valley, Goiás, Brazil. Revista Brasileira de Zoologia, vol. 24, no. 2, pp. 344-352. http://dx.doi.org/10.1590/S0101-81752007000200012.

ELMOOR-LOUREIRO, L.M.A., 2013. Distribution of the cladoceran Bosmina huaronensis Delachaux, 1918 and niche differentiation among populations from different biogeographic regions. Nauplius, vol. 21, no. 2, pp. 131-136. http://dx.doi. org/10.1590/S0104-64972013000200001.

ELMOOR-LOUREIRO, L.M.A., SANTOS-WISNIEWSKI, M.J. and ROCHA, O., 2013. Redescription of Alonella lineolata Sars, 1901 (Crustacea, Cladocera, Chydoridae) and its translocation to the subfamily Aloninae and to the new genus Bergamina gen. nov. Zootaxa, vol. 3630, no. 3, pp. 571-581. http://dx.doi.org/10.11646/ zootaxa.3630.3.11. PMid:26131533.

FERRAREZE, M. and NOGUEIRA, M.G., 2011. Importance of lateral lagoons for the zooplankton assemblages (Cladocera and Copepoda) in a large tropical reservoir. Oecologia Australis, vol. 15, no. 3, pp. 673-687. http://dx.doi.org/10.4257/oeco.2011.1503.07.

FERREIRO, N., FEIJOÓ, C., GIORGI, A. and LEGGIERI, L., 2011. Effects of macrophyte heterogeneity and food availability on structural parameters of the macroinvertebrate community in a Pampean stream. Hydrobiologia, vol. 664, no. 1, pp. 199-211. http://dx.doi.org/10.1007/s10750-010-0599-7.

FRYER, G., 1968. Evolution and adaptive radiation in the Chydoridae (Crustacea: Cladocera): a study in comparative functional morphology and ecology. Philosofical Transactions of the Royal Society of London. Series B, Biological Sciences, vol. 254 , no. 795 , pp. 221-382.

FULAN, J.A. and HENRY, R., 2006. The Odonata (Insecta) assemblage on Eichhornia azurea (Sw.) Kunth (Pontederiaceae) stands in Camargo Lake, a lateral lake on the Paranapanema River (state of São Paulo, Brazil), after an extreme inundation episode. Acta Limnologica Brasiliensia, vol. 18, no. 4, pp. 423-431.

GAZULHA, V., MONTÚ, M., MARQUES, D.M. and BONECKER, C.C., 2011. Effects of natural banks of free-floating plants on zooplankton community in a shallow subtropical lake in Southern Brazil. Brazilian Archives of Biology and Technology, vol. 54, no. 4, pp. 745-754. http://dx.doi.org/10.1590/S1516-89132011000400014.

GRENOUILLET, G. and PONT, D., 2001. Juvenile fishes in macrophyte beds: influence of food resources, habitat structure and body size. Journal of Fish Biology, vol. 59, no. 4, pp. 939-959. http://dx.doi.org/10.1111/j.1095-8649.2001.tb00163.x. 
GÜNTZEL, A.M., MELO, I.K.M., ROCHE, K.F., SILVA, V.F.B. and POMPIANI, P.G., 2010. Cladocerans from gut contents of fishes associated to macrophytes from Taquari River Basin, MS, Brazil. Acta Limnologica Brasiliensia, vol. 24, no. 1, pp. 97-102. http://dx.doi.org/10.1590/S2179-975X2012005000029.

HENRY, R. and NOGUEIRA, M.G., 2007. A represa de Jurumirim (São Paulo). In: R. HENRY, ed. Ecologia de reservatórios: estrutura, função e aspectos sociais. Botucatu: FUNDIBIO, pp. 651-686.

HINOJOSA-GARRO, D., MASON, C.F. and UNDERWOOD, G.J.C., 2010. Influence of macrophyte spatial architecture on periphyton and macroinvertebrate community structure in shallow water bodies under contrasting land management. Fundamental and Applied Limnology, vol. 177, no. 1, pp. 19-37. http://dx.doi. org/10.1127/1863-9135/2010/0177-0019.

KOŘÍNEK, V., 2002. Cladocera. In: C.H. FERNANDO, ed. $A$ guide to tropical freshwater zooplankton: identification, ecology and impact on fisheries. Leiden: Backhuys Publisehers, pp. 69123. cap. 3.

KOROVCHINSKY, N.M., 1992. Sididae \& Holopedidae (Crustacea: Daphniformes). In: H.J. DUMONT, ed. Guides to the identification of the microinvertebrates of the continental waters of the World. The Netherlands: SPB Academic Publishing. 84 p. vol. 3.

KOTOV,A.A. and STIFTER, P., 2006. Cladocera: family Ilyocryptidae (Brachiopoda: Cladocera: Anomopoda). In: H.J. DUMONT, ed. Guides to the identification of the microinvertebrates of the continental waters of the world. Leiden: Backhuys Publishers. 172 p. vol. 22.

MAIA-BARBOSA, P.M., PEIXOTO, R. and GUIMARÃES, A.S., 2008. Zooplankton in littoral waters of a tropical lake: a revisited biodiversity. Brazilian Journal of Biology $=$ Revista Brasileira de Biologia, vol. 68, no. 4, suppl., pp. 1069-1078. http://dx.doi. org/10.1590/S1519-69842008000500014. PMid:19197477.

MCABENDROTH, L., RAMSAY, P.M., FOGGO, A., RUNDLE, S.D. and BILTON, D.T., 2005. Does macrophyte fractal complexity drive invertebrate diversity, biomass and body size distributions? Oikos, vol. 111, no. 2, pp. 279-290. http://dx.doi. org/10.1111/j.0030-1299.2005.13804.X.

MEERHOFF, M., FOSALBA, C., BRUZZONE, C., MAZZEO, N., NOORDOVEN, W. and JEPPENSEN, E., 2006. An experimental study of habitat choice by Daphnia: plants signal danger more than refuge in subtropical lakes. Freshwater Biology, vol. 51, no. 7, pp. 1320-1330. http://dx.doi.org/10.1111/j.1365-2427.2006.01574.x.

MEERHOFF, M., IGLESIAS, C., MELLO, F.T., CLEMENTE, J.M., JENSEN, E., LAURIDSEN, T.L. and JEPPESEN, E., 2007. Effects of habitat complexity on community structure and predator avoidance behaviour of littoral zooplankton in temperate versus subtropical shallow lakes. Freshwater Biology, vol. 52, no. 6, pp. 1009-1021. http://dx.doi.org/10.1111/j.1365-2427.2007.01748.x.

MELO, R. and HEBERT, P.D.N., 1994. A taxonomic reevaluation of North American Bosminidae. Canadian Journal of Zoology, vol. 72, no. 10, pp. 1808-1825. http://dx.doi.org/10.1139/z94-245.

MESCHIATTI, A.J., ARCIFA, M.S. and FENERICH-VERANI, N., 2000. Fish communities associated with macrophytes in Brazilian floodplain lakes. Environmental Biology of Fishes, vol. 58, no. 2, pp. 133-143. http://dx.doi.org/10.1023/A:1007637631663.

NOGUEIRA, M.G., 2001. Zooplankton composition, dominance and abundance as indicators of environmental compartmentalization in Jurumirim Reservoir (Paranapanema River), São Paulo,
Brazil. Hydrobiologia, vol. 455, no. 1-3, pp. 1-18. http://dx.doi. org/10.1023/A:1011946708757.

NOGUEIRA, M.G., GEORGE, D.G. and JORCIN. A., 2003. Estudo do zooplâncton em zonas litorâneas lacustres: um enfoque metodológico. In: R. HENRY, org. Ecótonos nas Interfaces dos ecossistemas aquáticos. São Carlos: RiMa, pp. 83-128.

NOGUEIRA, M.G., HENRY, R. and MARICATTO, F.E., 1999. Spatial and temporal heterogeneity in the Jurumirim Reservoir, São Paulo, Brazil. Lakes and Reservoirs: Research and Management, vol. 4, no. 3-4, pp. 107-120. http://dx.doi.org/10.1046/j.14401770.1999.00086.x.

ORLOVA-BIENKOWSKAJA, M.J., 1998. A revision of the cladoceran genus Simocephalus (Crustacea, Daphaniidae). Bulletin of the Natural History Museum, vol. 64, no. 1, pp. 1-62.

PANARELLI, E.A., CASANOVA, S.M.C., NOGUEIRA, M.G., MITSUKA, P. and HENRY, R., 2003. A comunidade zooplanctônica ao longo de gradientes longitudinais no rio Paranapanema/represa de Jurumirim (São Paulo, Brasil). R. HENRY, org. Ecótonos nas Interfaces dos ecossistemas aquáticos. São Carlos: RiMa, pp. 129-160.

PANARELLI, E.A., CASANOVA, S.M.C. and HENRY, R., 2008. The role of resting eggs in the recovery of zooplankton community in a marginal lake of the Paranapanema River (São Paulo, Brazil), after a long drought period. Acta Limnologica Brasiliensia, vol. 20, no. 1, pp. 73-88.

PANARELLI, E.A., CASANOVA, S.M.C. and HENRY, R., 2010. Secondary production and biomass of Cladocera in marginal lakes after the recovery of their hydrologic connectivity in a river-reservoir transition zone. Lakes and Reservoirs: Research and Management, vol. 15, no. 4, pp. 319-334. http://dx.doi. org/10.1111/j.1440-1770.2010.00444.x.

SARTORI, L.P., NOGUEIRA, M.G., HENRY, R. and MORETTO, E.M., 2009. Zooplankton fluctuations in Jurumirim Reservoir (São Paulo, Brazil): a three-year study. Brazilian Journal of Biology = Revista Brasileira de Biologia, vol. 69, no. 1, pp. 1-18. http:// dx.doi.org/10.1590/S1519-69842009000100002. PMid:19347141.

SINEV, A.Y. and ELMOOR-LOUREIRO, L.M.A., 2010. Three new species of chydorid cladocerans of subfamily Aloninae (Branchipoda: Anomopoda: Chydoridae) from Brazil. Zootaxa, vol. 2390 , pp. 1-25.

SMIRNOV, N.N., 1992. The Macrothricidae of the World. In: H.J. DUMONT, ed. Guides to the identification of the microinvertebrates of the continental waters of the World. The Netherlands: SPB Academic Publishing. 152 p. vol. 1.

SMIRNOV, N.N., 1996. Cladocera: the Chydorinae and Sayciinae (Chydoridae) of the World. In: H.J. DUMONT, ed. Guides to the identification of the microinvertebrates of the continental waters of the World. The Netherlands: SPB Academic Publishing. 195 p. vol. 11.

TARKOWSKA-KUKURYK, M. and KORNIJÓW, R., 2008. Influence of spatial distribution of submerged macrophytes on Chironomidae assemblages in shallow lakes. Polish Journal of Ecology, vol. 56, no. 4, pp. 569-579.

THOMAZ, S.M. and CUNHA, E.R., 2010. The role of macrophytes in habitat structuring in aquatic ecosystems: methods of measurement, causes and consequences on animal assemblages' composition and biodiversity. Acta Limnologica Brasiliensia, vol. 22, no. 2, pp. 218-236. http://dx.doi.org/10.4322/actalb.02202011. 
THOMAZ, S.M., DIBBLE, E.D., EVANGELISTA, L.R., HIGUTI, J. and BINI, L.M., 2008. Influence of aquatic macrophyte habitat complexity on invertebrate abundance and richness in tropical lagoons. Freshwater Biology, vol. 53, pp. 358-367.

TREMEL, B., FREY, S.E., YAN, N.D., SOMERS, K.M. and PAWSON, T.W., 2000. Habitat specificity of littoral Chydoridae (Crustacea, Branchiopoda, Anomopoda) in Plastic Lake, Ontario, Canada. Hydrobiologia, vol. 432, no. 1-3, pp. 195-205. http:// dx.doi.org/10.1023/A:1004023003179.

VAN DAMME, K. and DUMONT, H.J., 2008. Further division of Alona Baird, 1843: separation and position of Coronatella
Dybowski \& Grochowski and Ovalona gen.n. (Crustacea: Cladocera). Zootaxa, vol. 1960, pp. 1-44.

VAN DAMME, K., KOTOV, A.A. and DUMONT, H.J., 2010. A checklist of names in Alona Baird 1843 (Crustacea: Cladocera: Chydoridae) and their current status: an analysis of the taxonomy of a lump genus. Zootaxa, vol. 2330, pp. 1-63.

VAN DAMME, K., SINEV, A.Y. and DUMONT, H.J., 2011. Separation of Anthalona gen. n. from Alona Baird, 1843 (Branchiopoda: Cladocera: Anomopoda): morphology and evolution of scraping stenothermic alonines. Zootaxa, vol. 2875, pp. 1-64. 